\title{
Relasi Zakat dan Pajak: \\ Studi Kasus Badan Amil Zakat Nasional Kabupaten Malang dan Kantor Pelayanan Pajak Pratama Kepanjen Malang
}

\author{
Siti Umus Salamah \\ Fakultas Syariah UIN Maulana Malik Ibrahim Malang \\ yaa.emmaj@yahoo.com
}

\begin{abstract}
Abstrack:
This article aims to describe the differences in Act No. 38 of 1999 and Act No. 23 of 2011 and explain the relation zakat and tax after the enactment of Law No. 23 of 2011 in the district of Malang. Based on the above study it can be concluded that there are some differences between the Act No. 38 of 1999 and Act No. 23 of 2011 as a centralized power management of zakat, which is rigid in Indian conditions amil zakat institutions, as well as criminal penalties for managers who violate the provisions of the law. Zakat Management Act while recognizing the new zakat and tax relations. This was followed up administratively by BAZNAS Malang and the Tax Office Pratama Malang. Nonetheless, the public interest to use as the basis of proof of payment of zakat tax deduction has not been significant in the district of Malang.

Artikel ini bertujuan mendeskripsikan perbedaan Undang-Undang No. 38 Tahun 1999 dan Undang-Undang No. 23 Tahun 2011 serta menjelaskan relasi zakat dan pajak pasca berlakunya Undang-Undang No. 23 Tahun 2011 di wilayah Kabupaten Malang. Berdasarkan kajian di atas dapat disimpulkan bahwa ada beberapa perbedaan antara Undang-Undang No. 38 Tahun 1999 dan Undang-Undang No. 23 Tahun 2011 seperti sentralisasi yang kekuasaan pengelolaan zakat, syarat yang rigid dalam pendian lembaga amil zakat, serta adanya sanksi pidana bagi pengelola yang melanggar ketentuan undang-undang. Undang-Undang Pengelolaan Zakat yang baru tetap mengakui relasi zakat dan pajak. Hal ini ditindaklanjuti secara administratif oleh BAZNAS Kabupaten Malang dan Kantor Pelayanan Pajak Pratama Kabupaten Malang. Meskipun demikian, animo masyarakat menggunakan bukti pembayaran zakat sebagai dasar pengurang pajak belum signifikan di wilayah Kabupaten Malang.
\end{abstract}

Kata Kunci: zakat; pajak; kesejahteraan

\section{Pendahuluan}

Zakat dapat digunakan sebagai instrumen kemandirian sosial bagi fakir miskin. Melalui dana filantropi ini, mereka yang berada di bawah atau kerak kemiskinan dapat memenuhi kebutuhan dasarnya. Berdasarkan data BAZNAS, potensi zakat di Indonesia pada tahun 2015 sebesar Rp. 280 triliun dan realisasinya diperkirakan Rp. 4 triliun atau kurang dari 1,4\% dari potensinya. ${ }^{1}$ Potensi zakat dapat digunakan oleh negara untuk melaksanakan programprogram pembangunan, khususnya pemberantasan kemiskinan, pembangunan infrastuktur, dan kesejahteraan rakyat Indonesia. Wacana sinergi antara keduanya telah digagas sejak lama, baik dalam dunia akademik maupun kebijakan. Sebagaimana telah diketahui bahwa pajak

\footnotetext{
1 Hartono, "Mengungkap Tabir Zakat Di Indonesia," accessed May 13, 2015, http://www.pajak.go.id/content/article/mengungkap-tabir-zakat-di-indonesia. Jurisdictie: Jurnal Hukum dan Syariah Vol. 6 No. 1 Tahun 2015
} 
merupakan iuran wajib yang dipungut oleh negara baik oleh pemerintah pusat maupun pemerintah daerah berdasarkan peraturan perundang-undangan, tidak mendapat imbalan, digunakan untuk kepentingan masyarakat dan negara. ${ }^{2}$ Pajak merupakan salah satu alat untuk mencapai tujuan negara. Pajak digunakan dalam rangka menjalankan fungsi pemerintahan, baik rutin maupun pembangunan. ${ }^{3}$

Sinergi zakat dan pajak di Indonesia diatur dalam Undang-Undang No. 38 Tahun 1999 tentang Pengelolaan Zakat. Tujuannya agar wajib pajak tidak terkena beban ganda, yaitu kewajiban membayar zakat dan pajak. Kesadaran membayar zakat diharapkan juga dapat meningkatkan kesadaran masyarakat membayar pajak.4 Meskipun demikian, zakat yang dapat mengurangi beban pajak terutang adalah Badan Amil Zakat (BAZ) atau Lembaga Amil Zakat (LAZ) yang dibentuk atau disahkan oleh pemerintah. ${ }^{5}$ Namun, berdasarkan penelitian yang dilakukan oleh Sri Andriani dan Fitha Fathya pelaksanaan program zakat sebagai instrumen pengurang pajak belum berjalan maksimal karena kurangnya sosialisasi. Banyak masyarakat yang belum mengetahui adanya regulasi tentang zakat sebagai pengurang pajak yang harus dibayarkan. ${ }^{6}$

Pada tahun 2011, pemerintah bersama DPR merevisi regulasi pengelolaan zakat di Indonesia dengan Undang-Undang Nomor 23 Tahun 2011. Perubahan ini memunculkan kontroversi dan keresahan di masyarakat. Berdasarkan persoalan di atas, artikel ini bertujuan memberikan penjelasan tentang perbedaan substansi Undang-Undang No. 38 Tahun 1999 dan Undang-Undang No. 23 Tahun 2011 tentang pengelolaan zakat serta menjelaskan relasi zakat dan pajak pasca munculnya Undang-Undang No. 23 Tahun 2011 khususnya di Badan Amil Zakat Nasional Kabupaten Malang dan Kantor Pelayanan Pajak Pratama Kabupaten Malang.

\section{Metode Penelitian}

Adapun jenis penelitian yang digunakan pada penelitian ini adalah penelitian hukum empiris. Dalam penelitian ini, data-data yang dicari adalah mengenai relasi pajak dan zakat pasca Undang-Undang No. 23 Tahun 2011 tentang pengelolaan Zakat. Sedangkan subjek dalam penelitian ini adalah BAZNAS Kabupaten Malang dan Kantor Pelayanan Pajak Pratama Kepanjen Malang. Pendekatan penelitian yang digunakan dalam penelitian ini adalah deskriptif kualitatif. ${ }^{7}$ Sumber data primer $^{8}$ penelitian ini adalah pengelola BAZNAS Kabupaten Malang yaitu Drs. H. Ali Nasith, M.Si. M.Pdi dan staff Kantor Pelayanan Pajak Pratama Kepanjen Malang yaitu Eni Budilestari. Data primer diperoleh dengan cara melakukan wawancara mendalam kepada informan penelitian. ${ }^{9}$ Sumber data sekunder penelitian ini adalah Undang-Undang tentang zakat dan pajak, buku-buku teks pendukung yang memberikan informasi mengenai zakat dan pajak.

\footnotetext{
${ }^{2}$ Undang-Undang Nomor 28 Tahun 2007 tentang Perubahan Ketiga Atas Undang-Undang Nomor 6 Tahun 1983 tentang Ketentuan Umum dan Tata Cara Perpajakan LN. Tahun 2007 No. 85

${ }^{3}$ M. Ali Hasan, Zakat dan Infak: Salah Satu Solusi Mengatasi Problema Sosial Di Indonesia (Jakarta: Kencana, 2006), 82.

${ }^{4}$ Undang-Undang Nomor38 Tahun 1999 tentang Pengelolaan Zakat LN. Tahun 1999 No. 164

5 Erikson Wijaya, "Tinjauan Singkat Pajak Dan Zakat," accessed August 4, 2014, http://www.pajak.go.id/content/article/tinjauan-singkat-pajak-dan-zakat.

${ }^{6}$ Sri Andriani and Fitha Fathya, "Zakat Sebagai Pengurang Pajak Penghasilan Pada Badan Amil Zakat," Jurnal Risen Akuntansi \& Komputerisasi Akuntansi 4, no. 1 (2013): 31.

${ }^{7}$ Burhan Ashshofa, Metode Penelitian Hukum (Jakarta: Rineka Cipta, 2001), 16.

${ }^{8}$ Amiruddin and Zainal Asikin, Pengantar Metode Penelitian Hukum (Jakarta: RajaGrafindo Persada, 2012 ), 30.

${ }^{9}$ Bahder Johan Nasution, Metode Penelitian Ilmu Hukum (Bandung: Mandar Maju, 2008), 167.

Jurisdictie: Jurnal Hukum dan Syariah Vol. 6 No. 1 Tahun 2015
} 


\section{Hasil dan Pembahasan \\ Regulasi Pengelolaan Zakat di Indonesia Sejak Tahun 1999-2011}

Zakat merupakan bagian yang tidak terpisahkan dalam kehidupan seorang muslim. Selain bernuansa ibadah, yaitu membersikah dan mensucikan harta, zakat juga memiliki dimensi sosial kemasyarakatan seperti munculnya kedermawanan, solidaritas, empati, mencegah kriminalitas akibat kemiskinan. ${ }^{10}$ Sebagai negara berpenduduk mayoritas beragama Islam, regulasi pengelolaan zakat di Indonesia juga mendapat perhatian dari negara. Pada tahun 1999, telah disahkan Undang-Undang No. 38 Tahun 1999 tentang Pengelolaan Zakat. Pengelolaan zakat dalam Undang-Undang No. 38 Tahun 1999 dilakukan berdasarkan asas iman dan takwa, keterbukaan dan kepastian hukum sesuai dengan Pancasila dan UndangUndang Dasar 1945. Undang-Undang No. 38 Tahun 1999 menekankan pada aspek pengelolaan zakat mulai dari perencanaan, pengorganisasian, pelaksanaan, dan pengawasan terhadap pengumpulan dan pendistribusian serta pendayagunaan dana zakat. Selain itu, di dalam Undang-Undang No. 38 Tahun 1999 terdapat pasal-pasal yang mengatur tentang prinsip-prinsip dan teknis pengelolaan zakat.

Dalam pengelolaan zakat, pemerintah membentuk organisasi yang bertugas mengumpulkan, mendistribusikan dan mendayagunakan zakat. Organisasi ini diatur dalam BAB III pasal 6 dan 7 tentang Organisasi Pengelolaan Zakat. Dalam pasal 6 Undang-Undang No. 38 Tahun 1999 menjelaskan bahwa pemerintah memiliki hak penuh atas pembentukan Badan Amil Zakat (BAZ) sesuai dengan tingkat kekuasaan wilayah masing-masing, yaitu: 1) tingkat nasional oleh Presiden atas usul Menteri; 2) daerah propinsi oleh gubernur atas usul kepala kantor wilayah departemen agama propinsi; 3) daerah kabupaten atau daerah kota oleh bupati atau wali kota atas usul kepala kantor departemen agama kabupaten atau kota; 4) daerah kecamatan oleh camat atas usul kepala kantor urusan agama kecamatan. Semua di atas memiliki hubungan kerja yang bersifat koordinatif, konsultatif dan informatif sesuai dengan tingkatan masing-masing. Selain itu masyarakat juga memiliki peran aktif dalam pelaksanaan pengelolaan zakat. Dalam hal ini masyarakat dapat membentuk Lembaga Amil Zakat (LAZ) sebagai wadah untuk peran masyarakat dalam pengelolaan zakat tersebut. Hal ini diatur dalam pasal 7 Bab III UndangUndang No. 38 Tahun 1999 tentang Organisasi Pengelolaan Zakat.

Dalam undang-undang ini, BAZ maupun LAZ memiliki tugas yang sama, yaitu mengumpulkan, mendistribusikan dan mendayagunakan zakat yang diatur dalam pasal 8 Undang-Undang No. 38 Tahun 1999. Selain itu dalam pasal 9 Undang-Undang No. 38 Tahun 1999 BAZ maupun LAZ memiliki tugas bertanggung jawab kepada pemerintah sesuai dengan tingkatannya, sehingga dalam undang-undang ini BAZ yang dibentuk oleh pemerintah dan LAZ yang dibentuk oleh masyarakat memiliki posisi yang sejajar dalam pengelolaan zakat, baik dalam tugas, wewenang maupun pertanggung jawabannya. Selain itu dalam melaksanakan tugasnya BAZ dan LAZ tidak hanya mengurusi persoalan zakat. Hal tersebut diatur dalam pasal 13 Undang-Undang No. 38 Tahun 1999 yang menyatakan bahwa Badan Amil Zakat dapat menerima harta selain zakat seperti infaq, shadaqah, wasiat waris dan kafarat.

Keanggotaan dalam pasal 6 ayat 4 Undang-Undang No. 38 Tahun 1999 mengatur secara umum mengenai pengurus Badan Amil Zakat terdiri atas unsur masyarakat yaitu Ulama, kaum cendekiawan dan tokoh masyarakat serta dari unsur pemerintah yang memenuhi persyaratan 52 tertentu antara lain memiliki sifat amanah, adil, berdedikasi, profesional, dan berintegritas tinggi. Dalam keanggotaan LAZ tidak diatur secara jelas dalam UndangUndang No. 38 Tahun 1999 karena pembentukan LAZ tersebut dibentuk langsung oleh masyarakat sehingga yang diatur dalam Undang-Undang No. 38 Tahun 1999 bukan mengenai

${ }^{10}$ Fakhruddin Al-Muhsin, Ensiklopedi Mini Zakat (Mudah, Ringkas, Praktis), trans. Agus Abu Aufa (Bogor: Darul Ilmi, 2011), 8.

Jurisdictie: Jurnal Hukum dan Syariah Vol. 6 No. 1 Tahun 2015 
keanggotaan melainkan pembentukan LAZ. Tugas pengawasan terhadap kinerja BAZ dan LAZ dilaksanakan oleh pengawas yang dibentuk oleh pemerintah. Hal ini diatur dalam pasal 6 ayat 5 dan oleh masyarakat yang memiliki peran keikutsertaan dalam pengawasan atas tugas yang diberikan oleh BAZ dan LAZ. Dalam pengawasan ini diatur dalam Undang-Undang No. 38 Tahun 1999 pasal 18 dan pasal 20. Terkait dengan sanksi Undang-Undang No. 38 Tahun 1999 menjabarkannya dalam pasal 21. Pasal 21 ayat 1 mengatur sanksi atas kelalaian administrasi yang dilakukan oleh petugas BAZ dan atau LAZ yaitu kelalaiannya dalam pencatatan baik dengan tidak mencatat atau mencatat dengan tidak benar harta zakat, infaq, shadaqah, wasiat, hibah, waris dan kafarat diancam dengan hukuman kurungan selamalamanya tiga bulan dan atau denda sebanyak-banyaknya Rp. 3.000.000,00 (tiga juta rupiah) yang mana hal tersebut dalam ayat 2 digolongkan kedalam sebuah pelanggaran. 53 Selain itu dalam kasus penyalahgunaan atau penyelewengan (tindak pidana) atas harta zakat, infaq, shadaqah, wasiat, hibah, waris dan kafarat yang dilakukan oleh petugas BAZ dan atau LAZ dalam UndangUndang No. 38 Tahun 1999 pasal 21 ayat 3 maka diancam dengan sanksi sesuai dengan undang-undang yang berlaku.

Seiring dengan problematika pengelolaan zakat yang semakin kompleks, pada tanggal 20 Oktober tahun 2011, DPR dan Presiden mengesahkan Undang-Undang No. 23 Tahun 2011 tentang Pengelolaan Zakat untuk menggantikan Undang-Undang No. 38 Tahun 1999. Dalam undang-undang pengelolaan zakat ini diatur beberapa hal yang berbeda, yaitu: Pemerintah memiliki hak penuh atas pembentukan Organisasi Pengelolaan Zakat. Hal ini diatur dalam pasal 5 ayat 1 Undang-Undang No. 23 Tahun 2011 bahwa untuk melaksanakan pengelolaan zakat, Pemerintah (Menteri) membentuk BAZNAS dalam skala Nasional yang memiliki fungsi perencanaan, pelaksanaan, pengendalian dan pelaporan atas pengumpulan, pendistribusian, dan pendayagunaan zakat. Sedangkan, untuk membantu dalam pelaksanaan tugas BAZNAS dalam skala Nasional maka menteri dapat membentuk BAZNAS pada tingkat Provinsi dan Kabupaten atau Kota atas usulan kepala daerah pada tingkatan masing-masing setelah 54 mendapat pertimbangan dari BAZNAS di tingkat Nasional. Hal ini diatur dalam pasal 15 ayat 1 sampai 5 Undang-Undang No. 23 Tahun $2011 .^{11}$

Pada pasal 16 Undang-Undang No. 23 Tahun 2011 mengatur tentang pembentukan Unit Pengumpulan Zakat (UPZ). Unit dibentuk oleh BAZNAS untuk membantu tugas dari BAZNAS pada instansi pemerintah, Badan Usaha Milik Negara, Badan Usaha Milik Daerah, perusahaan swasta, dan perwakilan Republik Indonesia di luar negeri serta dapat membentuk UPZ pada tingkat kecamatan, kelurahan atau lainnya. Terkait Organisasi Pengelolaan Zakat lainnya yaitu LAZ, UndangUndang No. 23 Tahun 2011 ini memberi batasan hanya LAZ yang mendapatkan izin dari Menteri atau Pejabat yang ditunjuk oleh menteri yang diakui oleh negara. Selain itu, pembentukan LAZ bukan dibentuk oleh masyarakat seperti yang diatur dalam undang-undang sebelumnya, melainkan dibentuk oleh Organisasi Kemasyarakatan yang harus memenuhi ketentuan yang dituangkan dalam pasal 18 ayat 2 UndangUndang No. 23 Tahun 2011 yang berbunyi: “(2) Izin sebagaimana dimaksud pada ayat (1) hanya diberikan apabila memenuhi persyaratan paling sedikit: 1. Terdaftar sebagai organisasi kemasyarakatan Islam yang mengelola bidang pendidikan, dakwah, dan sosial; 2. Berbentuk lembaga berbadan hukum; 3. Mendapat rekomendasi dari BAZNAS; 4. Memiliki pengawas syariat; 5. Memiliki kemampuan teknis, administratif, dan keuangan untuk melaksanakan kegiatannya; 6. Bersifat nirlaba; 7. Memiliki program untuk mendayagunakan zakat bagi kesejahteraan umat; dan 8. Bersedia diaudit syariat dan keuangan secara berkala."

Tugas dan kewenangan Organisasi Pengelolaan Zakat dalam BAZNAS, LPZ dan UPZ memiliki tugas dan wewenang yang berbeda. Dalam pasal 7 ayat 1 Undang-Undang No. 23 Tahun 2011 menjelaskan tentang tugas BAZNAS yaitu perencanaan, pelaksanaan,

\footnotetext{
${ }^{11}$ Undang-Undang Nomor 23 Tahun 2011 tentang Pengelolaan Zakat LN. Tahun 2011 No. 115 Jurisdictie: Jurnal Hukum dan Syariah Vol. 6 No. 1 Tahun 2015
} 
pengendalian dan pelaporan atas pengumpulan, pendistribusian, dan pendayagunaan zakat. Sedangkan LAZ memiliki tugas membantu BAZNAS dalam pelaksanaan, pengumpulan, pendistribusian, dan pendayagunaan zakat. Hal tersebut di atur dalam pasal 17 UndangUndang No. 23 Tahun 2011. Dan UPZ memiliki tugas membantu BAZNAS hanya dalam pengumpulan zakat yang diatur dalam pasal 1 ayat 9 dan pasal 16 ayat 1 Undang-Undang No. 23 Tahun 2011.

Pelaksanaan pengumpulan, pendistribusian, dan pendayagunaan zakat oleh BAZNAS Kabupaten/Kota wajib dilaporkan dan dipertanggung jawabannya kepada BAZNAS ditingkat wilayah yang lebih tinggi dan pemerintah daerah di masing-masing, selanjutnya BAZNAS pusat melaporkan pertanggung jawabannya kepada menteri. Adapun LAZ berkewajiban melaporkan pertanggung jawabannya kepada BAZNAS dan pemerintah daerah di masingmasing tingkatan wilayah, yang mana hal ini di atur dalam pasal 29 Undang-Undang No. 23 Tahun 2011. Sehingga dari aturan tersebut pemerintah berupaya untuk mensentralisasi Organisasi Pengelolaan Zakat dengan memposisikan BAZNAS lebih tinggi dari pada LAZ. Selain itu terdapat aturan yang bersifat administratif yang diatur dalam pasal 23 UndangUndang No. 23 Tahun 2011 yang mewajibkan BASNAS atau LAZ memberikan bukti pembayaran atas zakat yang telah dibayarkan. Bukti pembayaran tersebut dapat digunakan oleh muzakki sebagai pengurang penghasilan kena pajak.

Dalam Undang-Undang No. 23 Tahun 2011 yang lebih detail mengatur tentang keanggotaan yaitu dalam pasal 8 Undang-Undang No. 23 Tahun 2011 bahwa anggota BAZNAS terdiri dari 11 orang, 8 orang dari unsur masyarakat dan 3 lainnya dari unsur pemerinta. Selanjutnya 57 masa jabatan serta pengangkatan atau pemberhentian anggota BAZNAS serta persyaratannya juga diatur dalam pasal 9, 10, 11dan 12 UndangUndang No. 23 Tahun 2011. Menteri dan pejabat daerah memiliki kewajiban membina dan mengawasi BAZNAS dan LAZ dalam melaksanakan tugasnya. Selain itu, masyarakat juga memiliki kontribusi dalam pengawasan atas tugas yang diberikan oleh BAZNAS dan LAZ. Sebagaimana diatur dalam Undang-Undang No. 23 Tahun 2011 Bab V tentang pengawasan dan pembinaan. Sanksi dalam Undang-Undang No. 23 Tahun 2011 diatur dalam pasal 26 ayat 1 yang menjelaskan sanksi administratif terhadap kelalaian atas tugas yang diemban oleh BAZNAS dan LAZ, yaitu terkait pasal 19 tentang pelaporan pertanggungjawaban LAZ kepada BAZNAS, pasal 23 tentang pemberian bukti pembayaran zakat, pasal 28 tentang pengolahan dan pendistribusian dana infak dan pasal 9 ayat 3 tentang pelaporan pertanggung jawaban BAZNAS kepada menteri berupa sanksi berupa peringatan tertulis, penghentian sementara dari kegiatan sapai pada pencabutan izin.

Undang-Undang No. 38 Tahun 1999 dan Undang-Undang No. 23 Tahun 2011 tentang Zakat terdapat beberapa poin penting dalam pengelolaan zakat, diantaranya ialah; Dalam pembentukan Organisasi Pengelolaan Zakat Undang-Undang No. 38 Tahun 1999 menjelaskan bahwa pembentukan BAZNAS di tingkat Provinsi, Kabupaten atau Kota dan Kecamatan adalah kewenangan dari Kepala Daerah atas usulan Kepala Kantor Departemen Agama pada masing-masing wilayah, sedangkan Undang-Undang No. 23 Tahun 2011 mengatur pembentukan BAZNAS di tingkat Provinsi, Kabupaten atau Kota adalah wewenang dari Menteri, kemudian pada tingkat kecamatan BAZNAS dapat bentuk UPZ untuk membantu tugas pengumpulan zakat. Dalam pembentukan LAZ Undang-Undang No. 38 Tahun 1999 mengatur bahwa pembentukan LAZ adalah wewenang masyarakat secara penuh, tetapi dalam Undang-Undang No. 23 Tahun 2011 terdapat pembatasan yaitu pembentukan LAZ adalah wewenang dari Organisasi Kemasyarakatan dengan ketentuan yang telah diatur di dalam UndangUndang No. 23 Tahun 2011 tersebut.

Dalam Tugas dan wewenang Organisasi Pengelolaan Zakat, dalam Undang-Undang No. 23 Tahun 2011 pemerintah mencoba membuat sentralisasi terhadap Organisasi Pengelolaan Zakat dengan memposisikan BAZNAS lebih tinggi dari LAZ, dengan demikian menjadikan Jurisdictie: Jurnal Hukum dan Syariah Vol. 6 No. 1 Tahun 2015 
adanya perbedaan tugas antara BAZNAS dan LAZ, yaitu LAZ bertugas membantu tugas BAZNAS dalam pelaksanaan, pengumpulan, pendistribusian, dan pendayagunaan zakat yang sebelumnya dalam Undang-Undang No. 38 Tahun 1999 BAZNAS dan LAZ memiliki tugas pokok yang sama. Selain itu dalam pasal 23 Undang-Undang No. 23 Tahun 2011 terdapat tugas tambahan yang bersifat administratif yang mewajibkan BASNAS atau LAZ memberikan bukti pembayaran atas zakat yang dibayarkan kemudian dapat digunakan oleh muzaki sebagai pengurang penghasilan kena pajak. Pengawasan BAZNAS dan LAZ terdapat pengalihan tugas yang diatur dalam Undang-Undang No. 38 Tahun 1999 bahwa pengawasan merupakan tugas dari petugas yang dibentuk oleh pemerintah di dalam BAZNAS sedangkan dalam Undang-Undang No. 23 Tahun 2011 menyatakan bahwa pengawasan BAZNAS dan LAZ dilakukan oleh menteri serta Kepala Daerah di masing-masing Wilayah dan masyarakat juga berperan aktif dalam pengawasan terhadap BAZNAS dan LAZ.

Perbedaan yang mendasar terkait Undang-Undang No. 23 Tahun 2011 dan UndangUndang No. 30 Tahun 1999 sebagaimana tabel berikut:

Tabel 1. Perbendingan Regulasi Pengelolaan Zakat Tahun 1999 dan 2011

\begin{tabular}{|c|c|c|c|}
\hline No & $\begin{array}{c}\text { Objek } \\
\text { Perbedaan }\end{array}$ & $\begin{array}{c}\text { Undang-Undang No. } 30 \\
\text { Tahun } 1999 \\
\end{array}$ & $\begin{array}{c}\text { Undang-Undang No. } 23 \\
\text { Tahun } 2011 \\
\end{array}$ \\
\hline 1. & $\begin{array}{l}\text { Pembentukan } \\
\text { BAZ }\end{array}$ & $\begin{array}{l}\text { Pembentukan BAZNAS } \\
\text { dibentuk oleh pemerintah pada } \\
\text { tingkat Nasional, oleh Gubernur } \\
\text { pada tingkat Provinsi, oleh } \\
\text { Bupati atau Wali kota pada } \\
\text { tingkat Kabupaten atau Kota } \\
\text { dan oleh Camat pada tingkat } \\
\text { Kecamatan (Pasal 6) }\end{array}$ & $\begin{array}{l}\text { BAZNAS Di semua tingkatan } \\
\text { mulai dari dari tingkat } \\
\text { Nasional sampai ke tingkat } \\
\text { Kota dan Kabupaten dibentuk } \\
\text { oleh Menteri (Pasal } 5 \text { dan } 15 \text { ) }\end{array}$ \\
\hline
\end{tabular}

\begin{tabular}{|c|c|c|c|}
\hline 2. & $\begin{array}{l}\text { Pembentukan } \\
\text { BAZ ditingkat } \\
\text { Kecamatan }\end{array}$ &  & $\begin{array}{l}\text { Ditingkat Kecamatan dan } \\
\text { Kelurahan } \\
\text { Kabupaten maupun Kota dapat } \\
\text { membentuk UPZ ( Pasal 16) }\end{array}$ \\
\hline 3. & $\begin{array}{l}\text { Wewenang } \\
\text { pengelolaan } \\
\text { zakat }\end{array}$ & $\begin{array}{l}\text { Posisi BAZNAS dan LAZ } \\
\text { sejajar dalam pengelolaan zakat. } \\
\text { ( Pasal 8) }\end{array}$ & $\begin{array}{l}\text { Posisi BAZNAS lebih tinggi } \\
\text { dari LAZ dalam pengelolaan } \\
\text { zakat } \\
\text { (Pasal 17) }\end{array}$ \\
\hline 4. & $\begin{array}{l}\text { Tugas BAZ dan } \\
\text { LAZ }\end{array}$ & $\begin{array}{l}\text { BAZ dan LAZ memiliki tugas } \\
\text { yang sama ( Pasal 8) }\end{array}$ & $\begin{array}{l}\text { LAZ memiliki tugas membantu } \\
\text { pelaksanaan dari tugas } \\
\text { BAZNAS (Pasal 17) }\end{array}$ \\
\hline 5. & Kean & $\begin{array}{l}\text { Tidak adanya pasal yang } \\
\text { mengatur tentang keanggotaan } \\
\text { secara jelas ( Pasal } 6 \text { ayat } 5 \text { ) }\end{array}$ & $\begin{array}{l}\text { Adanya pasal yang mengatur } \\
\text { tentang keanggotaan (Pasal 8) }\end{array}$ \\
\hline 6. & $\begin{array}{l}\text { Wewenang } \\
\text { dalam } \\
\text { pembentukan } \\
\text { LAZ }\end{array}$ & $\begin{array}{l}\text { LAZ dibentuk oleh masyarakat } \\
\text { (Pasal 7) }\end{array}$ & $\begin{array}{l}\text { LAZ dibentuk oleh organisasi } \\
\text { kemasyarakatan Islam ( Pasal } \\
18 \text { ayat } 2 \text { ) }\end{array}$ \\
\hline 7. & $\begin{array}{l}\text { Wewenang } \\
\text { dalam } \\
\text { pengelolaan } \\
\text { zakat }\end{array}$ & $\begin{array}{lr}\text { Masyarakat } & \text { memiliki } \\
\text { wewenang dalam } & \text { mengelola } \\
\text { zakat } & \end{array}$ & $\begin{array}{l}\text { Hanya yang diberi izin saja } \\
\text { yang boleh mengelola zakat ( } \\
\text { Pasal } 18 \text { ayat } 1)\end{array}$ \\
\hline
\end{tabular}




\begin{tabular}{lllll}
\hline 8. & $\begin{array}{l}\text { Pertanggung } \\
\text { jawaban }\end{array}$ & LAZ dan BAZ & melaporkan & LAZ melaporkan pertanggung \\
dan LAZ & pertanggung & jawabannya & jawabannya kepada BAZNAS \\
& kepada Pemerintah & (Pasal 19) & dan Pemerintah ( Pasal 19) \\
\hline
\end{tabular}

\section{Relasi Zakat dan Pajak Pasca Undang-Undang No. 23 Tahun 2011 di BAZNAS Kabupaten Malang dan Kantor Pelayanan Pajak Pratama Kepanjen Malang}

Sebelum tahun 2011, BAZNAS dan KPP Pratama belum memiliki hubungan yang signifikan. BAZNAS merupakan instansi keagamaan yang dibentuk oleh negara yang memiliki tugas mengelola dana zakat mulai dari pengumpulan, pengelolaan dan pendistribusiannya untuk kepentingan umat. Sedangkan KPP Pratama merupakan instansi negara yang mengumpulkan dana dari masyarakat, berupa pajak yang digunakan untuk kepentingan negara. Setelah disahkannya Undang-Undang No. 23 Tahun 2011, dalam pasal 22 dan 23 dinyatakan bahwa bukti pembayaran zakat dapat digunakan sebagai lampiran dalam pembayaran pajak, yang selanjutnya digunakan sebagai pengurang penghasilan kena pajak, hal ini tentunya meringankan biaya pajak yang harus dibayar oleh muzakki. Dengan demikian BAZNAS maupun Kantor Pelayanan Pajak secara umum memiliki hubungan administratif dalam melaksanakan Undang-Undang No. 23 Tahun 2011.

BAZNAS Kabupaten Malang berusaha secara maksimal melaksanakan tugas-tugas yang diberikan, hal ini dapat dilihat dari pengumpulan dana ZIS yang dilakukan oleh BAZNAS Kabupaten Malang yang diperoleh dari 33 Kecamatan, sebagaimana tabel berikut:

Tabel 2. Perolehan dana ZIS di BAZNAS Kabupaten Malang

\begin{tabular}{ccc}
\hline No & Tahun & Dana ZIS \\
\hline 1 & 2011 & Rp. 559,365,968 \\
\hline 2 & 2012 & Rp. 589,176,659 \\
\hline 3 & 2013 & Rp. 577,010,370 \\
\hline
\end{tabular}

Tabel di atas menunjukkan bahwa BAZNAS Kabupaten Malang saat ini rata-rata dalam setiap bulannya mampu mengumpulkan dana sebesar Rp. 47,932,028. Jumlah tersebut tidaklah sedikit mengingat tidak setiap orang membayarkan zakat nya kepada BAZNAS. Untuk memaksimalkan dana ZIS yang dapat dikumpulkan oleh BAZNAS Kabupaten Malang tentunya memerlukan upaya untuk memberikan penyuluhan kepada masyarakat akan pentingnya membayar zakat. hal ini menjadi salah satu program BAZNAS Kabupaten Malang dengan mengadakan presentasi 2 bulan 1 kali di daerah-daerah yang menjadi wilayah wewenang BAZNAS Kabupaten Malang, selain itu BAZNAS Kabupaten Malang juga mensosialisasikan perihal UndangUndang. No. 23 Tahun 2011 dalam presentasi yang dilakukannya. Dalam Pelaksanaan Undang-Undang No. 23 Tahun 2011 khususnya pasal 23 yang menjadi salah satu tugas pokok BAZNAS Kabupaten Malang, dalam hal ini Ali Nasith selaku sekertaris BAZNAS mengatakan:

"Mulai dari disahkannya Undang-Undang No. 23 Tahun 2011 saya rasa BAZNAS Kabupaten Malang telah melaksanakannya secara maksimal, termasuk memberikan bukti pembayaran yang kemudian dapat digunakan sebagai pengurang penghasilan kena pajak yangharus dibayarkan."

BAZNAS Kabupaten Malang juga telah memberikan bukti pembayaran zakat kepada Muzakki untuk digunakan sebagai pengurang penghasilan kena pajak, dengan demikian masyarakat (Muzakki) memiliki peran penting dalam penggunaan haknya yang di atur dalam pasal 22 Undang-Undang No. 23 Tahun 2011. Kantor Pelayanan Pajak Pratama Kabupaten Malang juga memberikan respon terhadap pemberlakuan Undang-Undang No. 23 Tahun Jurisdictie: Jurnal Hukum dan Syariah Vol. 6 No. 1 Tahun 2015 
2011, khususnya terkait bukti pembayaran zakat dapat digunakan untuk mengurangi penghasilan kena pajak. Berkaitan dengan adanya aturan ini Eni Budilestari yang menjadi staf bagian pengawasan dan konsultasi 1 di kantor pajak Pratama Kepanjen mengatakan:

"Dalam pelaksanakan Undang-Undang No. 23 Tahun 2011 Kantor Pajak Patama merujuk pada Peraturan Direktur Jendral Pajak Nomor PER-15/PJ/2012 tentang perubahan peraturan Jenderal Pajak Nomor PER-33/PJ/2011 tentang Badan/Lembaga yang dibentuk atau disahkan oleh pemerintah yang ditetapkan sebagai penerima zakat atau sumbangan keagamaan yang sifatnya wajib yang dapat dikurangkan dari penghasilan bruto"

Adapun badan/lembaga sebagai penerima zakat atau sumbangan keagamaan yang sifatnya wajib yang dapat dikurangkan dan penghasilan bruto adalah Badan Amil Zakat Nasional berdasarkan Keputusan Presiden Nomor 8 Tahun 2001 tanggal 17 Januari 2001 yaitu: Pertama, Badan Amil Zakat Nasional (BAZNAS) tingkat pusat hingga tingkat Kabupaten/Kota; Kedua, Lembaga Amil Zakat (LAZ) sebagai berikut: a) LAZ Dompet Dhuafa Republika; b) LAZ Yayasan Amanah Takaful; c) LAZ Pos Keadilan Peduli Umat; d) LAZ Yayasan Baitulmaal Muamalat; e) LAZ Yayasan Dana Sosial Al Falah; f) LAZ Baitul Maal Hidayatullah berdasarkan Keputusan Menteri Agama Nomor 538 Tahun 2001 tanggal 27 Desember 2001;g) LAZ Persatuan Islam; h) LAZ Yayasan Baitul Maal Umat Islam PT Bank Negara Indonesia (Persero) Tbk.; i) LAZ Yayasan Bangun Sejahtera Mitra Umat; j) LAZ Dewan Da'wah Islamiyah Indonesia; k) LAZ Yayasan Baitul Maal Bank Rakyat Indonesia; 1) LAZ Baitul Maal wat Tamwil; m) LAZ Baituzzakah Pertamina; n) LAZ Dompet Peduli Umat Daarut Tauhiid (DUDT); o) LAZ Yayasan Rumah Zakat Indonesia; Ketiga, Lembaga Amil Zakat, Infaq, dan Shadaqah (LAZIS) sebagai berikut: a) LAZIS Muhammadiyah; b) LAZIS Nandlatul Ulama (LAZIS NU); dan c) LAZIS Ikatan Persaudaraan Haji Indonesia (LAZIS IPHI). ${ }^{12}$

BAZNAS Kabupaten Malang dan Kantor Pelayanan Pajak Pratama Kepanjen Malang memiliki hubungan secara administratif berdasarkan Pasal 22 Undang-Undang No. 23 Tahun 2011 dan Peraturan Direktur Jendral Pajak Nomor PER-15/PJ/2012. Bukti pembayaran zakat yang dikeluarkan oleh BAZNAS dilampirkan dalam pembayaran pajak maka petugas Kantor Pajak akan memasukkan pembayaran zakat tersebut ke dalam kolom penghasilan neto dalam SPT pembayaran pajak sebagaimana dalam formulir SPT Tahunan 1170 S kolom penghasilan neto berikut:

\footnotetext{
${ }^{12}$ Peraturan Direktur Jenderal Pajak Nomor PER-15/PJ/2012 tentang Perubahan Peraturan Direktur Jenderal Pajak Nomor PER-33/PJ/2011 tentang Badan/Lembaga yang Dibentuk atau Disahkan oleh Pemerintah yang Ditetapkan Sebagai Penerima Zakat atau Sumbangan Keagamaan yang Sifatnya Wajib yang Dapat Dikurangkan dari Penghasilan Bruto
} 


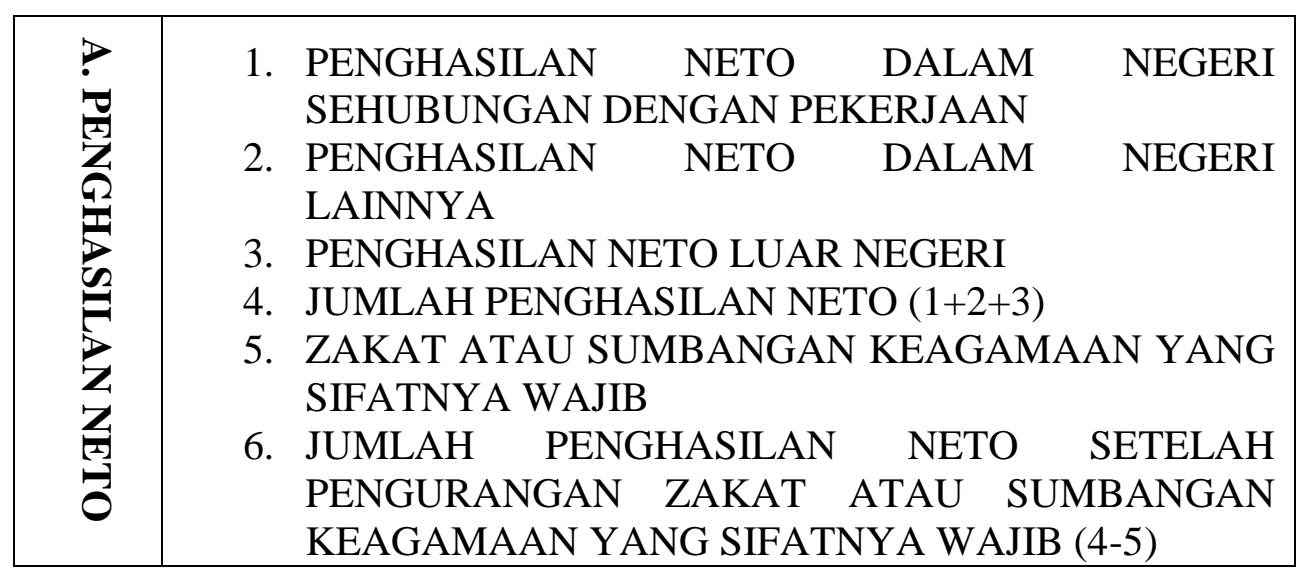

Dari kutipan tabel di atas posisi zakat atau sumbangan keagamaan yang sifatnya wajib adalah sebagai pengurang penghasilan neto, sehingga yang dihitung sebagai penghasilan kena pajak adalah penghasilan neto setelah dikurangi pembayaran zakat atau sumbangan keagamaan yang sifatnya wajib. Terkait hal tersebut BAZNAS dan Kantor Pelayanan Pajak sampai saat ini belum melakukan kumunikasi secara khusus terkait relasi kedua instansi negara tersebut yang diatur dalam Undang-Undang No. 23 Tahun 2011 dan Peraturan Direktur Jendral Pajak Nomor PER-15/PJ/2012. Berkaitan dengan hal tersebut Ali Nasith selaku sekertaris BAZNAS menganggap hal itu tidak perlu dilakukan karena BAZNAS dan Kantor Pelayanan Pajak memiliki tugas yang berbeda dan diatur dalam aturan yang berbeda pula. Dalam pelaksaan Undang-Undang No. 23 Tahun 2011 Pasal 22 BAZNAS Kabupaten Malang maupun Kantor Pelayanan Pajak Pratama Kepanjen Malang telah masing-masing telah berupaya melaksanakan tugasnya dengan baik, terlihat dari upaya dari BASNAS yang mencoba memberikan arahan kepada masyarakat dalam program 2 bulanan yang berupa presentasi serta sosialisasi Undang-Undang No. 23 Tahun 2011 kepada masyarakat secara berkala, selain itu Kantor Pelayanan Pajak Pratama Kepanjen Malang juga berperan aktif dalam mensosialisasikan aturan dalam Peraturan Direktur Jendral Pajak Nomor PER15/PJ/2012 kepada setiap pembayar pajak untuk menggunakan haknya yang berupa pengurangan penghasilan kena pajak dengan melampirkan bukti pembayaran zakat. Terkait efektifitas pelaksanaan Pasal 22 Undang-Undang No. 23 Tahun 2011 tentunya tidak hanya melibatkan BAZNAS dan Kantor Pelayanan Pajak akan tetapi melibatkan masyarakat secara langsung, dalam hal ini masyarakat memiliki peran yang sangat penting dalam pelaksanaan Pasal 22 Undang-Undang No. 23 Tahun 2011 melihat BAZNAS dan Kantor Pelayanan Pajak Pratama Kepanjen Malang telah melakukan tugasnya secara maksimal dan telah mensosialisasikan hal tersebut kepada masyarakat. mengenai hal ini Eni Budilestari yang menjadi staf bagian pengawasan dan konsultasi 1 di Kantor Pajak Pratama Kabupaten Malang mengungkapkan:

"Selama ini pembayar pajak yang menyertakan bukti pembayaran zakat masih sedikit, jumlahnya pun tidak lebih dari 1 persen dari jumlah pembayar zakat."

Adapun rekapitulasi wajib pajak yang menyertakan bukti pembayaran zakat di Kantor Pajak Pratama Kabupaten Malang sebagai berikut:

Tabel 3. Pembayar Pajak yang Menyertakan Bukti Pembayaran Zakat

\begin{tabular}{cccc}
\hline No & Tahun & $\begin{array}{c}\text { Jumlah Pembayar } \\
\text { Pajak }\end{array}$ & $\begin{array}{c}\text { Jumlah Pembayar Pajak Yang } \\
\text { menyertakan Bukti } \\
\text { Pembayaran Zakat }\end{array}$ \\
\hline 1 & 2011 & 15775 & 145 \\
\hline
\end{tabular}

Jurisdictie: Jurnal Hukum dan Syariah Vol. 6 No. 1 Tahun 2015 


\begin{tabular}{llll}
\hline 2 & 2012 & 12834 & 140 \\
\hline 3 & 2013 & 13347 & 180 \\
\hline
\end{tabular}

Tabel di atas menunjukkan bahwa pembayar pajak yang menyertakan bukti pembayaran zakatnya kurang dari 1 persen dari jumlah pembayar pajak. Meskipun demikian, jumlah pembayar pajak yang menyertakan bukti pembayaran zakat terjadi peningkatan yang signifikan pada tahun 2013. Salah satu sebab minimnya animo masyarakat menyertakan bukti pembayaran zakat karena penyertaan tersebut bersifat tidak mengikat melainkan hak dari masyarakat yang bersangkutan.

\section{Kesimpulan}

Berdasarkan kajian di atas dapat disimpulkan bahwa perbedaan yang mendasar antara Undang-Undang No. 38 Tahun 1999 dan Undang-Undang No. 23 Tahun 2011 tentang Pengelolaan Zakat adalah adanya sentralisasi yang dilakukan pemerintah dengan memposisikan BAZNAS di atas LAZ yang dulunya memiliki posisi yang sejajar sehingga LAZ berkewajiban menyampaikan laporan atas pengelolaan zakat kepada BAZNAS. Dalam Undang-Undang No. 23 Tahun 2011 pemerintah juga memperketat lembaga-lembaga amil zakat dengan memberikan persyaratan untuk memperoleh izin untuk melakukan pengelolaan zakat sehingga LAZ tersebut diakui oleh pemerintah. Dalam Undang-Undang No. 23 Tahun 2011 terdapat perubahan kewenangan dalam pembentukan BAZNAS di semua tingkatan yang saat ini menjadi wewenang menteri atas pertimbangan BAZNAS.

Relasi zakat dan pajak pasca Undang-Undang No. 23 Tahun 2011 di BAZNAS Kabupaten Malang dan Kantor Pelayanan Pajak Pratama Kepanjen Malang adalah adanya hubungan yang bersifat administratif antara BAZNAS Kabupaten Malang dan kantor pelayanan pajak Pratama Kepanjen Malang. Sebenarnya hal ini telah diatur dalam dalam Undang-Undang No. 38 Tahun 1999, yang kemudian ditegaskan kembali dalam Peraturan Pemerintah No. 60 Tahun 2010 tentang Zakat Atau Sumbangan Keagamaan Yang Sifatnya Wajib yang dapat dikurangkan dari Penghasilan Bruto, Undang-Undang No. 23 Tahun 2011 tentang Pengelolaan Zakat dan Peraturan Direktur Jendral Pajak Nomor PER-15/PJ/2012. Sehingga menjadikan aturan tersebut saling menguatkan. Dengan demikian diharapkan kepada masyarakat berperan aktif dalam pelaksanaan Undang-Undang No 23 Tahun 2011 dengan menyertakan bukti pembayaran zakat kepada Kantor Pelayanan Pajak supaya beban pajak yang harus dibayarkan oleh masyarakat menjadi lebih ringan.

\section{Daftar Pustaka}

Al-Muhsin, Fakhruddin. Ensiklopedi Mini Zakat (Mudah, Ringkas, Praktis). Translated by Agus Abu Aufa. Bogor: Darul Ilmi, 2011.

Amiruddin, and Zainal Asikin. Pengantar Metode Penelitian Hukum. Jakarta: RajaGrafindo Persada, 2012.

Andriani, Sri, and Fitha Fathya. "Zakat Sebagai Pengurang Pajak Penghasilan Pada Badan Amil Zakat.” Jurnal Risen Akuntansi \& Komputerisasi Akuntansi 4, no. 1 (2013).

Ashshofa, Burhan. Metode Penelitian Hukum. Jakarta: Rineka Cipta, 2001.

Hartono. "Mengungkap Tabir Zakat Di Indonesia.” Accessed May 13, 2015. http://www.pajak.go.id/content/article/mengungkap-tabir-zakat-di-indonesia.

Hasan, M. Ali. Zakat dan Infak: Salah Satu Solusi Mengatasi Problema Sosial Di Indonesia. Jakarta: Kencana, 2006.

Peraturan Direktur Jenderal Pajak Nomor PER-15/PJ/2012 tentang Perubahan Peraturan Direktur Jenderal Pajak Nomor PER-33/PJ/2011 tentang Badan/Lembaga yang Dibentuk atau 
Disahkan oleh Pemerintah yang Ditetapkan Sebagai Penerima Zakat atau Sumbangan Keagamaan yang Sifatnya Wajib yang Dapat Dikurangkan dari Penghasilan Bruto Nasution, Bahder Johan. Metode Penelitian Ilmu Hukum. Bandung: Mandar Maju, 2008.

Wijaya, Erikson. "Tinjauan Singkat Pajak Dan Zakat." Accessed August 4, 2014. http://www.pajak.go.id/content/article/tinjauan-singkat-pajak-dan-zakat.

Undang-Undang Nomor38 Tahun 1999 tentang Pengelolaan Zakat LN. Tahun 1999 No. 164

Undang-Undang Nomor 23 Tahun 2011 tentang Pengelolaan Zakat LN. Tahun 2011 No. 115 